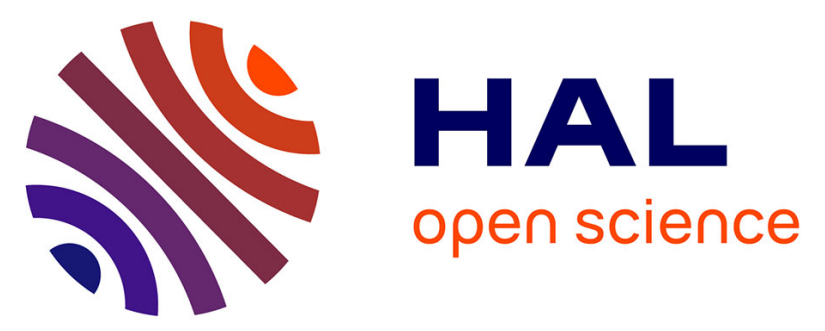

\title{
Bioanalytical characterisation of multiple endocrine- and dioxin-like activities in sediments from reference and impacted small rivers.
}

Said Kinani, Stéphane Bouchonnet, Nicolas Creusot, Sophie Bourcier, Patrick Balaguer, Jean-Marc Porcher, Sélim Aït-Aïssa

\section{To cite this version:}

Said Kinani, Stéphane Bouchonnet, Nicolas Creusot, Sophie Bourcier, Patrick Balaguer, et al.. Bioanalytical characterisation of multiple endocrine- and dioxin-like activities in sediments from reference and impacted small rivers.. Environmental Pollution, 2010, 158 (1), pp.74-83. 10.1016/j.envpol.2009.07.041 . ineris-00453475

\section{HAL Id: ineris-00453475}

https://hal-ineris.archives-ouvertes.fr/ineris-00453475

Submitted on 4 Feb 2010

HAL is a multi-disciplinary open access archive for the deposit and dissemination of scientific research documents, whether they are published or not. The documents may come from teaching and research institutions in France or abroad, or from public or private research centers.
L'archive ouverte pluridisciplinaire HAL, est destinée au dépôt et à la diffusion de documents scientifiques de niveau recherche, publiés ou non, émanant des établissements d'enseignement et de recherche français ou étrangers, des laboratoires publics ou privés. 
1 Bioanalytical characterisation of multiple endocrine- and dioxin-like activities in

2 sediments from reference and impacted small rivers

3

4 Said Kinani ${ }^{\mathrm{a}, \mathrm{b}, *}$, Stéphane Bouchonnet ${ }^{\mathrm{b}, *}$, Nicolas Creusot $^{\mathrm{a}}$, Sophie Bourcier ${ }^{\mathrm{b}}$, Patrick

5 Balaguer ${ }^{\mathrm{c}}$, Jean-Marc Porcher ${ }^{\mathrm{a}}$ and Sélim Aït-Aïssa ${ }^{\mathrm{a}, 1, *}$

6

7 a Unité d'Ecotoxicologie, Institut National de 1'Environnement Industriel et des Risques 8 (INERIS), BP2, F-60550 Verneuil en Halatte, France.

9 b Département de Chimie des Mécanismes Réactionnels, Ecole Polytechnique, 91128

10 Palaiseau Cedex, France.

$11{ }^{\mathrm{c}}$ Institut National de la Santé et de la Recherche Médicale (INSERM), U896, Montpellier, F1234298 , France.

13

141 : Corresponding author: Tel +33 344556 511, Fax +33 344556767

$15 *$ E-mail adresses : selim.ait-aissa@ineris.fr (Sélim Aït-Aïssa), said@dcmr.polytechnique.fr 16 (Said Kinani), stephane.bouchonnet@dcmr.polytechnique.fr (Stéphane Bouchonnet). 


\section{Abstract}

19 A comprehensive evaluation of organic contamination was performed in sediments sampled

20 in two reference and three impacted small streams where endocrine disruptive (ED) effects in

21 fish have been evidenced. The approach combined quantitative chemical analyses of more than 50 ED chemicals and in vitro bioassays allowing the quantification of receptor-mediated activities, namely estrogen (ER), androgen (AR), dioxin (AhR) and pregnane $\mathrm{X}$ (PXR) receptors. At the most impacted sites, chemical analyses showed the presence of natural estrogens, organochlorine pesticides, parabens, polycyclic aromatic hydrocarbons (16 PAHs), bisphenol A and alkylphenols, while synthetic steroids, myco-estrogens and phyto-estrogens were not detected. Determination of toxic-equivalent amounts showed that 28 to $96 \%$ of estrogenic activities in bioassays $(0.2-6.3 \mathrm{ng} / \mathrm{g} 17 \beta$-estradiol equivalents) were explained by $17 \beta$-estradiol and estrone. PAHs were major contributors (20-60\%) to the total dioxin-like activities. Interestingly, high PXR and (anti)AR activities were detected; however, analysed compounds could not explain the measured biological activities. Keywords: river sediment; endocrine disrupting chemicals; in vitro bioassays; GC-MS \& LCMS analysis; mass balance analysis detected in French river sediments using a panel of in vitro bioassays and analytical methods. 


\section{Introduction}

The rapid industrial and urban development which occurred in the second half of the $20^{\text {th }}$ century allowed the emergence of millions of persistent anthropogenic chemicals in our environment without prior study of their toxicity. In recent years, a newly defined category of these chemicals, with the potential to interact with the endocrine system have emerged and aroused considerable interest of scientific communities. Named endocrine disruptingchemicals (EDCs), these substances are defined as "exogenous agents that interfere with the synthesis, secretion, transport, binding, action, or elimination of natural hormones which are responsible for maintenance of homeostasis, reproduction, development and/or behavior" (Kavlock et al., 1996). In the aquatic environment, occurring EDCs are very diverse in terms of chemical nature and origins (Vos et al., 2000).

Up to date, most attention has been directed to identifying estrogenic chemicals, i.e. those capable of binding to and activating the estrogen receptor (ER), because many of the effects reported in wildlife appear to be a consequence of feminization of males (Sumpter et al., 2005). However, many environmental contaminants can interfere with other molecular targets involved in the regulation of the endocrine system. These include other nuclear receptors like androgen receptor (AR), pregnane X receptor (PXR, e.g. Mnif et al., 2007) as well as steroidogenesis enzymes like aromatase (e.g. Laville et al., 2006). EDCs can also act via indirect mechanisms such as (anti)estrogenic effect mediated by aryl hydrocarbon receptor (AhR) ligands through an ER/AhR cross-talk dependent mechanism (Othake et al., 2003, 2007). Therefore, a comprehensive assessment of EDC hazard should take into account the ability of chemicals to interfere with different targets of the endocrine system (Houtman et al., 2004).

Regarding the large diversity of EDCs and their effects, bioanalytical approaches using mechanism-based biological screening tools have emerged to monitor such substances in 
complex environmental mixtures (Eggen and Segner, 2003). In particular, in vitro assays using reporter gene activation in stably transfected cell lines provide robust, sensitive and specific bioassays to screen and quantify endocrine activities in environmental samples.

Combining such tools with powerful chemical analyses within integrated approaches permits to identify key toxicants to be monitored in the environment (Brack, 2003). By using such bioanalytical approaches, the occurrence of EDCs and their effects to aquatic organisms has been several times reported in different industrialised countries like the United Kingdom (e.g. Jobling et al., 2006) or the Netherlands (e.g. Vethaak et al., 2005). However in France, much fewer data have been reported. Recent studies showed occurrence of steroid estrogens and alkylphenols in effluents from sewage treatment plants (Labadie and Budzinski, 2005, Muller et al., 2008) or in water and sediment from the Seine River (Fenet et al., 2003; Cargouet et al., 2004). More recently, abnormal elevated levels of vitellogenin and spigging, used as biomarkers of estrogen and androgen exposure respectively, have been reported in three-spine stickleback (Gasterosteus aculeatus) sampled in different small streams subjected to diffuse pollution like agricultural run-off or domestic effluents (Sanchez et al., 2008). Thus, more investigation is needed in order to characterise and identify key EDCs in French aquatic ecosystems.

This study aimed at performing a comprehensive evaluation of the chemical contamination by EDCs in sediments sampled in small streams at sites where endocrine disruptive effects in fish have been previously evidenced (Sanchez et al., 2007, Sanchez et al., 2008). The five selected sites, located in the North of France, were representative of different levels of water and ecological quality (Table 1). For this purpose, we used a combined approach involving i) targeted chemical analyses of more than 50 chemicals (Table 2) selected on the basis of both their environmental occurrence and their known EDC potency, and ii) a panel of in vitro bioassays that allowed the detection of different receptor-mediated activities, namely ER, AR, 
AhR and PXR. Since all activities were detected in at least two of the five studied sites, the contribution of analyzed EDCs in the biological activities detected by the bioassays was estimated by comparing toxic-equivalent quantities from both approaches.

\section{Materials and methods}

\subsection{Chemicals and reagents}

List, abbreviation and source of analytical standards are given in Table 2. Flutamide (Flut), 3(4,5-dimethylthiazol-2-ol)-2,5-diphenyltetrasodium bromide tetrazolium (MTT), 5adihydrotestosterone (DHT), as well as the analytical internal standards including $\left[{ }^{13} \mathrm{C}_{6}\right] 4-\mathrm{n}$ nonylphenol, $\left[{ }^{2} \mathrm{H}_{2}\right] 17 \beta$-estradiol, $\left[{ }^{2} \mathrm{H}_{10}\right]$ phenanthrene, $\left[{ }^{2} \mathrm{H}_{10}\right]$ acenaphthene, $\left[{ }^{2} \mathrm{H}_{12}\right]$ perylene and $\left[{ }^{2} \mathrm{H}_{12}\right]$ chrysene were purchased from Sigma-Aldrich (St Quentin Fallavier, France). ICI 182,780 (ICI) and 2,3,7,8-tetrachlorodibenzo-p-dioxin (TCDD) were obtained from Tocris Bioscience (Ellisville, USA) and Promochem (Molsheim, France), respectively. All standards were of 98.1-99.9\% purity. Chromatographic-grade solvents: acetone, methanol, acetonitrile, dimethylsulfoxide (DMSO) and n-hexane were also purchased from Sigma-Aldrich. Stock solutions of $\beta$-E2 $2.72 \mathrm{~g} / \mathrm{L}$, DHT $2.90 \mathrm{~g} / \mathrm{L}$ and B[a]P $2.52 \mathrm{~g} / \mathrm{L}$ were prepared by dissolving crystalline compound in DMSO. A solution of TCDD was prepared by drying an aliquot of TCDD in methanol under a nitrogen stream and dissolving the residue in DMSO to reach a concentration of $3.22 \mathrm{~g} / \mathrm{L}$.

\subsection{Site description and sampling}

Surface sediment samples were collected in five rivers located in the North of France during July 2004. The selected stations presented different levels of impacts in terms of anthropogenic pressures, chemical contamination and impacts on fish populations (Table 1): 
112 the Aisne (Ais) and the Vallon du Vivier (VdV) rivers were considered as reference sites; the

113 Lézarde (Lez) as a moderately impacted site and the Réveillon (Rév) and Rhonelle (Rho) as

114 heavily impacted sites. At each site, at least five grab sediment samples were taken alongside

115 the river section of the study sites and were pooled to obtain an average sediment sample and

116 to minimize intra-site variability. All sediment samples were passed through a $2 \mathrm{~mm}$ sieve

117 pore, stored in aluminium boxes and immediately transferred to the laboratory where they

118 were stored at $-20{ }^{\circ} \mathrm{C}$ in order to inhibit biological activity until extraction.

\subsection{Extraction procedure}

121 The sediment samples were extracted as previously described (Kinani et al., 2008a). Briefly, 5

$122 \mathrm{~g}$ of lyophilised and homogenised sediment were extracted three times with $10 \mathrm{~mL}$ of a

123 hexane/acetone $(2: 1, \mathrm{v} / \mathrm{v})$ mixture. For each extraction step, the sample was sonicated $10 \mathrm{~min}$

124 (ENMA Transsonic 460/H, Frequency 50-60 Hz, Germany) at room temperature. The extracts

125 were combined and the supernatant was transferred to a $50 \mathrm{~mL}$ vial containing $1.0 \mathrm{~g}$ of

126 anhydrous sodium sulphate. The organic extracts were then centrifuged for $10 \mathrm{~min}$ at 3000

$127 \mathrm{rpm}$ and the supernatant was collected, filtered onto a $0.45 \mu \mathrm{m}$ Acrodisc CRPTFE Syringe

128 filter (GelmanSciences, USA), reduced to about $1 \mathrm{~mL}$ using rotary evaporation at $30{ }^{\circ} \mathrm{C}$ or

129 lower, evaporated to complete dryness under a gentle nitrogen stream and reconstituted into 1

$130 \mathrm{~mL}$ of the extraction solvent. The final extract was then divided into two parts, the first one

131 for chemical analysis and the second one for bioassay testing. The extraction solvent was

132 subsequently replaced by DMSO for bioassay experiments.

133

134 2.4. Cell cultures and in vitro bioassays

135 2.4.1. Estrogenic, PXR and (anti-)androgenic activities in reporter gene assays 
136 The estrogenic, PXR and (anti-)androgenic activities of the extracts were monitored by using the MELN, $\mathrm{HG}_{5} \mathrm{LN}-\mathrm{PXR}$ and MDA-kb2 reporter cell lines, respectively. The MELN cell line was obtained by stable transfection of MCF-7 human breast cancer cells by an ERE- $\beta$ GlobLuc-SVNeo plasmid (Balaguer et al., 2001). The $\mathrm{HG}_{5} \mathrm{LN}-\mathrm{PXR}$ cell line was derived from

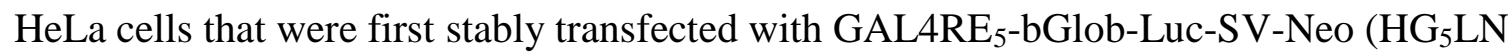

141 cells) before being stably transfected with the pSG5-GAL4(DBD)-hPXR(LBD)-puro plasmid 142 (Lemaire et al., 2006). The MDA-kb2 cell line (ATCC, \#CRL-2713) was derived from the 143 MDA-MB-453 human breast cancer cells. They were stably transfected by a MMTV 144 promoter-luciferase plasmid construct, which is under the control of endogenous AR and 145 glucocorticoid receptor (GR) (Wilson et al., 2002). All reporter cell lines were routinely 146 cultured in phenol red containing Dulbecco's Modified Eagle's Medium (DMEM), 147 supplemented with 5\% foetal calf serum (FCS), $1 \%$ nonessential amino acids and 148 penicillin/streptomycin $\left(50 \mathrm{U} / \mathrm{mL}\right.$ each) in a $5 \% \mathrm{CO}_{2}$ humidified atmosphere at $37{ }^{\circ} \mathrm{C}$. For

149 experiments, cells were left to incubate for two days in phenol red free DMEM supplemented 150 with 3\% dextran charcoal coated-FCS (DCC medium) before seeded in white opaque 96151 wells culture plates at a density of 50000 cells per well. Serial dilutions of reference 152 chemicals or organic extracts were added in triplicates $24 \mathrm{~h}$ later and then left to incubate for $15316 \mathrm{~h}$. In all assays, DMSO in the culture medium was always at $0.5 \% \mathrm{v} / \mathrm{v}$, including in cell 154 controls. At this concentration, it did not affect cell viability or luciferase activity. At the end 155 of the incubation period, the medium was removed and replaced by $50 \mu \mathrm{L}$ of DCC medium 156 containing $0.3 \mathrm{mM}$ of D-luciferin and the luminescence signal was measured in living cells 157 for 2 seconds per well with a microtiter plate luminometer ( $\mu$ Beta, Wallac). Relative 158 luminescence units (RLU) were converted to relative response units expressed as percent of 159 maximal luciferase activity induced by the positive controls: E2 $10 \mathrm{nM}$, SR12813 $0.3 \mu \mathrm{M}$, 160 DHT $10 \mathrm{nM}$ (for AR agonist activity) and DHT $0.3 \mathrm{nM}$ (for AR antagonist activity) in 
MELN, $\mathrm{HG}_{5} \mathrm{LN}-\mathrm{PXR}$ and MDA-kb2 cell lines, respectively. For ER and AR agonistic

162 responses, the specificity of luciferase induction by samples was checked by co-exposure experiments with $0.1 \mu \mathrm{M}$ ICI182,780 or $1 \mu \mathrm{M}$ flutamide, as reference ER and AR antagonists, respectively.

\subsubsection{Dioxin-like activity in PLHC-1 cell line}

166 The fish hepatic PLHC-1 cell line (ATCC, \#CRL-2406) was described by Ryan and

167 Hightower (1994). The cells were routinely grown at $30^{\circ} \mathrm{C}$ in E-MEM culture media 168 supplemented with $10 \%$ FCS and $1 \%$ antibiotics in a $5 \% \mathrm{CO}_{2}$ humidified atmosphere. For 169 experiments, cells were seeded in 96-well plates at a density of approximately 50000 cells

170 per well. After 24 hours of incubation, cells were exposed to test chemicals or sample extracts

171 for either a $4 \mathrm{~h}$ or $24 \mathrm{~h}$ incubation period, in order to differentiate between dioxin-like

172 compounds that are rapidly metabolized (e.g. PAHs) in the cells and dioxin-like chemicals 173 that are persistent in the cells (e.g. dioxins) (Louiz et al., 2008). Then, plates were processed

174 for 7-ethoxyresorufin-O-deethylase (EROD) activity in intact cells, following the protocol

175 previously described by Laville et al. (2004). Results were expressed as percent of EROD

176 activity induced by the positive control (TCDD $1 \mathrm{nM}$ ).

177 2.4.3. Cell viability

178 The effect of test compounds or samples on cellular viability in the different cell lines was

179 evaluated by using the methyl-thiazol-tetrazolium (MTT) assay (Mosmann, 1983), as

180 previously described (Laville et al., 2004).

\section{$182 \quad$ 2.5. Chemical analyses}

183 Two mass spectrometers coupled with chromatography have been used for the quantitative 184 analysis: a "CP3800" gas chromatograph system equipped with a "CP8400" autosampler and 185 coupled to a "Saturn 2000" ion trap mass spectrometer (Varian, Les Ulis, France) for the GC- 
MS and a "alliance 2690" liquid chromatography coupled to a Q-TOF Premier (Waters,

187 France) mass spectrometer for LC-MS/MS. Before performing the chemical analysis, a 188 portion of each extract was purified according to a method previously described by Hartmann 189 et al., (2007).

\subsubsection{GC-MS and GC-MS/MS analyses}

191 The chromatographic separation was performed with a $60 \mathrm{~m}$ "Factor four VF-10-MS" (10\%

192 phenyl, $90 \%$ methylpolysiloxane) capillary column (internal diameter: $0.25 \mathrm{~mm}$, film 193 thickness: $0.25 \mu \mathrm{m}$ ) from Varian. All experiments were performed by automatically injecting $1942.0 \mu \mathrm{L}$ of sample in the splitless mode at a rate of $50 \mu \mathrm{L} / \mathrm{s}$. Helium (99.999\% purity) was used 195 as the carrier gas at a constant flow of $1.0 \mathrm{~mL} / \mathrm{min}$ for PAHs analysis and at $1.4 \mathrm{~mL} / \mathrm{min}$ for 196 the other target compounds; and was held a constant flow by electronic pressure control. The

197 injector temperature was set to300 ${ }^{\circ} \mathrm{C}$. The split valve opened after 1 min, with a split ratio of $19835 / 100$. The manifold, ion trap source and transfer line temperatures were set to 120,220 and $199300^{\circ} \mathrm{C}$, respectively.

200 For the GC-MS analysis, except for organochlorines pesticides, all acquisition methods have 201 been previously described, the corresponding references being reported on Table 2 according 202 to the investigated chemical families. For $\mathrm{HCB}, \gamma-\mathrm{HCH}$, vinclozolin, metolachlor, $\alpha$ 203 endosulfan, $o, p$ '-DDT, $\beta$-endosulfan, methoxychlor and fenarimol analysis, the capillary 204 column was initially set at $80^{\circ} \mathrm{C}$ for thirty seconds, then ramped up to $280^{\circ} \mathrm{C}$ at $15{ }^{\circ} \mathrm{C} / \mathrm{min}$. 205 After $4.0 \mathrm{~min}$ at this value, the temperature was finally increased at $20{ }^{\circ} \mathrm{C} / \mathrm{min}$ up to 350 , 206 where it was held for $3.67 \mathrm{~min}$. The total duration of GC analysis was $21 \mathrm{~min}$. Ions were 207 formed under electro-ionization at $70 \mathrm{eV}$ with an emission current of $80 \mu \mathrm{A}$. The mass 208 spectrometer was operated using a hybrid acquisition mode alternating MS/MS and SIS 209 detection. 
LC/MS is equipped with an electrospray ionization (ESI) source operated in negative-ion

212 mode. The analytical column used was a Pursuit C18 (150 mm x $2.1 \mathrm{~mm}$ I.D., $5 \mu \mathrm{m}$ particle size, Varian, France) and a mobile phase consisting of acetonitrile (A) and water (B). The

214 gradient conditions were as followed: $25 \%$ of (A) and $75 \%$ of (B) for $2 \mathrm{~min}$, followed by a 215 linear increase to $75 \%$ (A) at $16 \mathrm{~min}$ and $2 \mathrm{~min}$ hold at 75\% (A). The flow rate was 0.2 $216 \mathrm{~mL} / \mathrm{min}$ and the injection volume was $20 \mu \mathrm{L}$. Only phytoestrogens were analysed by LC-MS.

217 The mass spectrometer was operated in order to record the MS/MS spectrum of deprotonated 218 pseudomolecular ion $[\mathrm{M}-\mathrm{H}]^{-}$. Collisions energies have been optimized between 20 to $30 \mathrm{eV}$ 219 for each compound to obtain three characteristic ions. The optimized instrument conditions 220 were as followed: capillary voltage $-3.4 \mathrm{kV}$, cone voltage, $50 \mathrm{~V}$; multiplier voltage, $2250 \mathrm{~V}$; 221 source temperature, $100^{\circ} \mathrm{C}$; desolvatation temperature, $450^{\circ} \mathrm{C}$. Nitrogen was used as both the 222 nebulizing $(50 \mathrm{~L} / \mathrm{h})$ and desolvatation gas $(700 \mathrm{~L} / \mathrm{h})$. Argon was used as collision gas at flow 223 $0.28(\mathrm{~mL} / \mathrm{min})$.

\subsection{Data analysis and determination of bioassay- and instrumental-derived toxic-}

\section{equivalents}

227 Sigmoid dose-response curves and efficient concentrations (i.e. $\mathrm{EC}_{25}$ and $\mathrm{EC}_{50}$, corresponding to concentrations of sediment extracts and chemical standards giving respectively 25 and $50 \%$ of the maximum luciferase or EROD activities) were determined with the Regtox 7.5

230 Microsoft Excel ${ }^{\mathrm{TM}}$ macro by using Hill equation (Vindimian et al., 1983) and freely available 231 at http://eric.vindimian.9online.fr. In all bioassays, significant responses were defined as those 232 greater than two times the standard deviation of the response obtained with DMSO (solvent 233 control). The dioxin-like, estrogenic, (anti)androgenic and PXR activities in samples derived 234 from bioassays were expressed as BaP- or TCDD-, E2-, DHT-, Flu- and SR12813-equivalents 235 (Bio-ref-EQs), respectively, which were determined as the ratio of the $\mathrm{EC}_{25}$ of the reference 
chemicals expressed as $\mathrm{ng} / \mathrm{L}$ or $\mu \mathrm{g} / \mathrm{L}$ to that of the sample expressed as equivalent gram of dry

237 weight sediment per litre (g EQ/L).

238 In order to estimate the contribution of analysed compounds to the total activity detected by a

239 bioassay, the measured concentrations (as ng/g sed wt) were converted to toxic-equivalent

240 activities derived from chemical analysis (Chem-ref-EQs), that is Chem-BaP-EQ, Chem-

241 TCDD-EQ, Chem-E2-EQ, Chem-DHT-EQ, Chem-Flu-EQ and Chem-SR12813-EQ, in each

242 respective bioassay. The Chem-ref-EQ were calculated according to the following equation:

243 Chem-ref-EQ $=\sum\left(\mathrm{C}_{\mathrm{i}} \times\right.$ ref- $\left.-\mathrm{EF}_{\mathrm{i}}\right)$, where, for a given chemical $i, \mathrm{C}_{\mathrm{i}}$ is the measured

244 concentration in a sample and ref-EF $\mathrm{EF}_{\mathrm{i}}$ is the inducing/inhibiting equivalent factor relative to

245 the reference ligand (i.e. BaP, TCDD, E2, DHT, Flu or SR12813) in a given bioassay. The

246 equivalent factors were calculated as follows: ref-EF $\mathrm{EF}_{25}$ of reference compound $/ \mathrm{EC}_{25}$ of

247 test compound $i$, on mass basis. Unless otherwise specified in Tables 3-5, ref-EFs of each

248 analysed compound were determined experimentally in each bioassay by establishing dose-

249 response curves for individual standard chemicals and by comparing them to that of the

250 reference compound. For instance, the 21 individual molecules listed in Table 4 were tested

251 for their ability to induce luciferase activity in MELN cells in our assay condition, and their

252 E2-equivalent factors (EEF) were then determined and used to calculate Chem-E2-EQ in the

253 samples. Finally, the ratio Chem-ref-EQ/Bio-ref-EQ allowed evaluating the contribution of

254 quantified compounds to the biological activity detected by the bioassay, i.e. a ratio near

$255100 \%$ means that all analysed compounds were explicative for biological results; otherwise

256 other non analysed compounds may be present in the samples.

\section{Results}

\subsection{Dioxin-like activity in river sediment extracts}


The dose-response curves for EROD induction by all organic extracts are shown in Figure 1.

261 All samples elicited significant EROD activity, indicating a general contamination by dioxin-

262 like compounds in all studied sites. Sample responses varied greatly depending on the studied

263 site and exposure duration. Except for the Ais site after $24 \mathrm{~h}$ of exposure, the dose-response

264 curves were fairly complete and almost parallel to the dose-response curves for reference

265 chemicals. This allowed us to use $\mathrm{EC}_{50}$ values for calculation of biological BaP-EQs and

266 TCCD-EQs (summarized in Table 3). The highest values were found for Lez site followed by 267 Rev, Rho, VdV and Ais. For all sediment extracts, EROD induction potency based on sample 268 concentration was higher after $4 \mathrm{~h}$ (Figure 1a) than after $24 \mathrm{~h}$ of exposure (Figure $1 \mathrm{~b}$ ) by 269 approximately one to three orders. This indicates a major contribution of non persistent 270 compounds, like PAHs, in the observed dioxin-like activities.

271 In order to test this hypothesis, the 16 priority PAHs were analysed in the extracts (Table 3 ).

272 Total PAHs concentrations indicate large between-site variations ranging from low

273 contamination levels in Ais site $(0.22 \mu \mathrm{g} / \mathrm{g}$ d.w. $)$ up to very high levels in Rev $(11.98 \mu \mathrm{g} / \mathrm{g}$

274 d.w.) and Lez $(23.08 \mu \mathrm{g} / \mathrm{g})$ d.w. sites. All sediment samples were dominated by high

275 molecular mass PAHs (4- to 6-ring).

276 The results given in Figure 2 showed that chemical- and bioassay-derived BaP-EQs and 277 TCCD-EQs were highly correlated $\left(r^{2}=0.99\right.$ and 0.97 , respectively), which confirmed the 278 involvement of PAHs in the detected biological activities at both exposure durations.

279 However, in all sediment extracts, the Chem-EQs were significantly lower than the Bio-EQs, 280 indicating that only a part of activity was explained by analyzed PAHs, which accounted for 281 approximately 20 to $60 \%$ and 16 to $40 \%$ of the BaP-EQs and TCCD-EQs measured in 282 PLHC-1, respectively. 
The presence of estrogenic compounds in sediment extracts was tested in the MELN reporter

286 cell line (Figure 3). Significant dose-dependent induction of luciferase activity was obtained

287 for all tested sediment extracts; the response magnitudes varied between $34 \%$ and $67 \%$ of

288 the maximal response elicited by $\beta$-E2. Moreover, co-exposure with the pure anti-estrogen

289 ICI-182,780 led to inhibition of the luminescent signal (data not shown), thus showing the

290 specific involvement of the ER in the detected effects and indicating that estrogenic

291 compounds were present in samples. Because the slopes of dose-response curves for different

292 sediment extracts were not parallel to that of $\beta$-E2, the use of $\mathrm{EC}_{25}$ was chosen to derive Bio-

293 E2-EQs. The Bio-E2-EQs values in the different extracts of sediment samples ranged from

2940.20 to $6.43 \mathrm{ng} / \mathrm{g}$ d.w (Table 4), with the highest activity in the Réveillon sediment extract.

295 Overall, the results presented in Table 4 showed that E1, $\beta$-E2, 1OHPyr and BPA were

296 detected in all samples, while the synthetic estrogens were never detected. The Réveillon site

297 was the most contaminated by xeno-estrogens, with measurable levels of natural estrogens,

298 alkylphenols, PAH metabolites, parabens, chlorinated pesticides, as well as detectable levels

299 of the zearalenone metabolites $\alpha$-ZAL and $\beta$-ZAL. $\alpha$-E2 was detected at Rhonelle and Aisne

300 sites; equol was present at Rhonelle site, while other myco- and phyto-estrogens were not

301 detected.

302 In Aisne, Vallon du Vivier and Lézarde sediments, the Bio-E2-EQs were totally explained

303 only by the presence of E1 and $\beta$-E2. However, differences between chemical and biological

304 measurements were observed for Réveillon and Rhonelle sediments with Chem-E2-EQs /

305 Biol-E2-EQs ratio values of 28 and 35\%, respectively. This suggests that these sediments may

306 contain estrogenic substances that were not included in our analytical methods.

308 3.3. (Anti) androgenic activity in river sediment extracts 
The dose-response curves show detectable androgenic activity in Aisne and Rhonelle samples

310 (Figure 4a), giving bioassay derived Bio-DHT-EQs values of 0.40 and $3.60 \mathrm{ng} / \mathrm{g}$ d.w.,

311 respectively. No androgenic activity was observed in the total sediment extract of Vallon du

312 Vivier, Lézarde and Réveillon sediments. In DHT co-exposure experiments (Figure 4b),

313 significant antiandrogenic activities were detected in Vallon du Vivier, Lézarde and Réveillon

314 samples, with respective Flu-EQs of 1.1, 7.4 and $32.5 \mu \mathrm{g} / \mathrm{g}$ d.w. By using the MTT test, no

315 cytotoxic effects could be observed for any working concentration of chemicals or organic

316 extracts (data not shown), thus indicating a specific effect on luciferase expression.

317 Determination of Chem-Flu-EQs showed that several anti-androgenic compounds were

318 present, but at concentrations that could explain only a very minor part of the observed

319 biological anti-androgenic activities (Table 5).

\subsection{Detection of PXR ligands in river sediment extracts}

322 No anti-PXR activity was noted in these samples (data not shown). However, all five samples

323 induced PXR activation in a dose-response manner (Figure 5a). The response magnitudes

324 were always inferior to the maximum response produced by positive control (SR 12813 at 3

$325 \mu \mathrm{M}$ ), and ranged from $30 \%$ to $73 \%$. Nevertheless, luciferase induction was specific to PXR

326 activation since no luciferase increase was noted in the parental $\mathrm{HG}_{5} \mathrm{LN}$ cell line, which

327 expresses only the GAL4-luciferase construct (Figure 5b). In $\mathrm{HG}_{5} \mathrm{LN}$ cell line, inhibition of

328 luciferase at high concentrations of Rev and Lez extracts was noted and reflected early toxic

329 events.

330 The low Chem-SR12813-EQ/Bio-SR12813 ratios showed that 4tOP, 4nNP, $\beta E 2$, E1, BPA,

331 endosulfan and $o, p$ '-DDT, which are known PXR ligands, poorly contributed to Bio-

332 SR12813-EQs in the samples (Table 5). Thus, the detected PXR activities were due to other

333 non analysed compounds. 


\section{Discussion}

337 In vitro profiling of sediment extracts showed multiple contaminations by dioxin-like and 338 endocrine active chemicals in small streams subjected to diffuse anthropogenic pollution. The 339 natural estrogens $\beta E 2$ and E1 and of PAH-like compounds were identified as main

340 contributors to estrogenic and dioxin-like activities, respectively, as determined by the 341 bioassays. Conversely, (anti)androgenic and PXR-mediated activities were detected but the 342 responsible compounds could not be identified using targeted chemical analyses.

\subsection{PAHs and EROD inducing compounds}

344 To some extent, the levels of PAHs measured in this study were in line with previous studies

345 in French freshwater watersheds. For instance, total PAH content ranged from 1.2 to 12.5

$346 \mu \mathrm{g} / \mathrm{g}$ of dry sediment at various sites from the Seine estuary (Cachot et al., 2006), and from

3472.3 to $41.3 \mu \mathrm{g} / \mathrm{g}$ in the Seine and Marne rivers sampled at urban sites nearby Paris (Ollivon et 348 al., 2002). In our study, the highest PAH levels were detected in areas subjected to mixed 349 anthropogenic pressures like the Réveillon, located in urban area upstream of Paris, and the 350 Lézarde river, located nearby a highway road. Conversely, the Aisne site was located in a non 351 urbanized area and was logically found as low contaminated by PAHs.

352 In all samples, PAH-like compounds were major contributors of dioxin-like activity, which 353 mostly explained by PAHs with molecular weights (M.W.) of 228 and 252; however analyzed 354 PAHs explained only part of overall activity in PLHC-1 cells. This is not surprising since the 355 priority PAHs are used as qualitative tracers of pollution and we noted that other high 356 molecular weight PAHs, presumably active, were present in the samples (Figure 2). Indeed, 357 fullscan chromatogram of Lézarde extract (data not shown) showed the presence of detectable 358 concentrations of several isomers of Chry (M.W. 228) and BaP (M.W. 252) that probably 
accounted for the detected activity in PLHC-1 cells, although this could not be tested in this

360 study. Similar conclusions have been reported by other studies that showed that a major 361 portion of AhR activity in river sediments was caused by nonpriority PAHs such as 362 methylated PAHs (e.g. Hollert et al., 2002; Brack et al., 2005). In addition, many other 363 dioxin-like compounds such as polychlorinated dibenzo-p-dioxins (PCDDs), polychlorinated 364 dibenzofurans (PCDFs), polychlorinated biphenyls (PCBs), polychlorinated naphthalenes 365 (PCNs) and some organochlorine pesticides, which were not included in the analyses, might 366 also explain the differences between chemical and biological analyses.

\section{2. (Xeno) Estrogens}

368 The contamination of aquatic ecosystems by estrogenic compounds has been few reported in

369 France as compared to other industrialized countries. Nonetheless, effluents from sewage

370 water treatment plant (SWTP) have been shown to be the source of steroid estrogens at 371 different locations (Labadie and Budzinski, 2005, Muller et al., 2008; Cargouet et al., 2004);

372 in surface waters, natural and synthetic estrogens were also described as main estrogenic 373 chemicals in the Seine river downstream Paris, France (Cargouet et al., 2004). In sediments 374 sampled downstream from a large SWTP in the Seine river, Fenet et al. (2003) reported that 375 alkylphenols were the main contributors to the estrogenic activities detected by MELN 376 bioassay while steroid estrogens were not measured in their study. This contrasts with the 377 very low contribution of alkylphenols measured in the present study where estrogenic 378 activities were predominantly explained by the natural estrogens $\beta E 2$ and E1. Since 379 alkylphenols are often considered as tracer compounds of water treatment effluents, the low 380 levels measured in our study could reflect the fact that our sites were not directly impacted by 381 SWTP effluents, the main source of aquatic pollution by alkylphenols. Nevertheless, other 382 studies in European countries have reported occurrence of steroid estrogens in river sediments 383 at similar levels than those found in our study, i.e. in the $0.3-5 \mathrm{ng} / \mathrm{g}$ range (Houtman et al., 
2006; Labadie and Hill, 2007; Reddy et al., 2005; Matějíček et al., 2007). Moreover, the large

385 contribution of natural estrogens to biological E2-EQs is in agreement with the study of

386 Houtman et al. (2006) who reported that E1 and $\beta E 2$ were responsible for more than $75 \%$ of

387 the estrogenic activity in sediments from Zierikze harbour, The Netherlands. In the low

388 impacted sites (Aisne, Vallon du Vivier and Lézarde), natural estrogens nearly explained 100

$389 \%$ of the estrogenic activity detected by the bioassay. Conversely, in Réveillon and Rhonelle

390 samples, only a part (28 and $35 \%$ ) of the estrogenic activity was explained by $\beta E 2$ and E1,

391 suggesting the presence of other xeno-estrogens in the samples. The Réveillon River is under

392 pressure of multiple sources of contamination and was indeed found to be contaminated by

393 many organic chemicals from agricultural (pesticides) and urban/industrial (BPA,

394 alkylphenols, parabens) origins. However, the targeted xeno-estrogens could not explain the

395 overall estrogenic of the sample, hence suggesting the presence of other ER ligands that were

396 not included in our analyses. This stresses the limits of the Chem-EQ based approach to

397 identify bioactive compounds in complex mixtures and argues for further investigations, for

398 instance by using effect directed analysis (EDA) approaches based on sample fractionation

399 and identification of bioassay active fractions (Brack, 2003), in order to better characterize the

400 contamination of this site by EDCs.

401 4.3. (Anti)androgenic activities

402 The occurrence of (anti)androgenic compounds in river sediments has been rarely reported as 403 compared to estrogenic or dioxin-like compounds. However, such compounds can be present 404 in river sediment since high levels of androgenic activities (1-15 ng DHT-EQ/g) were 405 quantified by using the YAS assay in sediment from United Kingdom estuaries (Thomas et 406 al., 2002). Natural androgenic steroids in sewage treatment effluents were identified as 407 possible source of contamination (Thomas et al., 2002). Recently, Urbatzka et al. (2007) 408 reported both androgenic and antiandrogenic activities in fractionated sediment extracts from 
the river Lambro, Italy, but the chemicals responsible for androgenicity in YAS assay were

410 not identified. Other studies have shown that pulp mill effluents (Jenkins et al., 2004) or

411 livestock feedlot effluents (Soto et al., 2004) are potential sources for androgens in the aquatic

412 environment. In our study, we detected androgenic activity (4 ng DHT-EQ/g) in Rhonelle

413 river sediment but the responsible compounds remain to be identified. In addition,

414 antiandrogenic activities were detected in three other sites (Rév, Lez and VdV). Although

415 several antiandrogenic chemicals were detected at these sites (i.e. BHT, BPA, alkylphenols,

416 pesticides, Table 5), the measured concentrations could explain only a minor part of the

417 activities measured in the MDA-kb2 bioassay. Therefore, the later were likely due to the

418 presence of other EDCs that have not been investigated in our chemical analyses.

\section{4.4. PXR activities}

420 To our knowledge, the present study is the first demonstration of PXR-mediated activity in

421 river sediments. The human PXR is known to be activated by a large panel of environmental

422 chemicals that belong to different classes, like pharmaceuticals, steroids, alkylphenols (Mnif

423 et al., 2007), polybrominated diphenyl ethers (Pacyniak et al., 2007), as well as various

424 pesticides (Lemaire et al., 2006). In the present study, human PXR activating substances were

425 detected in all analyzed samples, at concentrations in the $\mu \mathrm{g} / \mathrm{g}$ range in terms of SR12813-

426 EQs. Since PXR shares several ligands with the estrogen receptor (ER), it was hypothesized

427 that several of the (xeno)estrogens detected in our samples could have contributed to the

428 PXR-mediated activity. However, the Chem-SR12813-EQ/Bio-SR12813-EQ ratios showed

429 that, at the measured concentrations, analyzed (xeno)estrogens only poorly contributed to the

430 SR12813-EQ quantities determined by the bioassay. Thus, more investigations using

431 fractionation and isolation procedures will be necessary to characterize the compounds

432 responsible for PXR activation in sediments. One promising methodology will likely consist

433 in the use of purified PXR immobilized on columns in order to isolate PXR ligands from 
434 complex mixtures (Pillon et al., 2005; Balaguer et al., unpublished). It is expected that such

435 approach will allow identifying environmental PXR ligands and thus providing further useful

436 information on the toxicological relevance of detection of PXR activity in aquatic ecosystems.

\subsection{Comparison with fish biomarkers}

438 In the present study, toxicological profiling of sediments showed the presence of a wide range 439 of chemicals that could potentially affect different molecular targets, namely ER, AR, AhR 440 and PXR, involved in the regulation of the endocrine system of exposed organisms. At the 441 studied sites, recent biomarker studies in wild three-spine stickleback (Gasterosteus 442 aculeatus) revealed fish exposure to different chemical stress including endocrine disrupters 443 and dioxin-like compounds (Sanchez et al., 2007, Sanchez et al., 2008). Although statistical

444 correlation between fish biomarker and in vitro bioassays could not be tested because of the 445 small number of sites, some concordances between the two approaches were noted. For instance, vitellogenin induction in male stickleback has been evidenced in Réveillon and

447 Rhonelle rivers, which were the most active in the MELN assay (Table 4). In addition, female 448 stickleback from the Rhonelle River abnormally produced elevated levels of spigging, a male 449 glue protein synthesized in the kidney and used for building nest (Sanchez et al., 2008). This 450 suggested exposure to androgenic compounds, which correlates with the finding of AR451 mediated activity in MDA-kb2 cells in our study (Figure 4a). For dioxin-like activities, 452 significant EROD induction in male and female stickleback was reported in Réveillon and 453 Lézarde (Sanchez et al., 2007), the most active samples in the PLHC-1 assay (Table 3). On 454 the whole, the bioanalytical approach confirmed the multipollution context at impacted sites 455 like Réveillon and Rhonelle, and provided new information on possible causal agents for 456 abnormal endocrine responses in fish. Although we identified some of the chemicals 457 responsible for in vitro activities in sediment extracts, the direct extrapolation to fish exposure 458 is rather risky since it may depend on site specific characteristics that can influence pollutant 
partitioning between sediment, suspended matter and dissolved phase in the water column.

460 Thus, more investigation using appropriate sampling methods like passive samplers will be 461 needed in order to link chemical contamination by EDCs and fish exposure and effects.

462

463

\section{Conclusion}

In summary, this study reports for the first time the simultaneous assessment of multiple endocrine active and dioxin-like chemicals, in French river sediments sampled in small streams subjected to various diffuse pollutions. Besides the major contribution of natural steroids and PAH-like compounds to estrogenic and dioxin-like activities, (anti)androgenic and PXR-mediated activities were detected although the individual active compounds could not be identified using targeted chemical analyses. These samples are thus interesting candidates for further EDA studies, which are under progress in order to elucidate the causal agents.

\section{Acknowledgements}

The authors wish to thank Emmanuelle Maillot-Maréchal for excellent technical help with the cell cultures. This study was funded by the French Ministry of Ecology and Sustainable Development (Program 189), the “Agence Française de Sécurité Sanitaire de l’Environnement et du Travail” (AFSSET, RD-2005-02) and by a doctoral fellowship from the ANRT and INERIS (to SK).

\section{References}

Balaguer, P., Boussioux, A.M., Demirpence, E., Nicolas, J.C., 2001. Reporter cell lines are useful tools for monitoring biological activity of nuclear receptor ligands. Luminescence $16,153-158$. 
Brack, W., 2003. Effect-directed analysis: a promising tool for the identification of organic toxicants in complex mixtures? Analytical and Bioanalytical Chemistry 377, 397-407.

Brack, W., Schirmer, K., Erdinger, L., Hollert, H., 2005. Effect-directed analysis of mutagens and ethoxyresorufin-O-deethylase inducers in aquatic sediments. Environmental Toxicology and Chemistry 24, 2445-2458.

Cachot, J., Geffard, O., Augagneur, S., Lacroix, S., Le Menach, K., Peluhet, L., Couteau, J., Denier, X., Devier, M.H., Pottier, D., Budzinski, H., 2006. Evidence of genotoxicity related to high $\mathrm{PAH}$ content of sediments in the upper part of the Seine estuary (Normandy, France). Aquatic Toxicology 79, 257-267.

Cargouet, M., Perdiz, D., Mouatassim-Souali, A., Tamisier-Karolak, S., Levi, Y., 2004. Assessment of river contamination by estrogenic compounds in Paris area (France). Science of the Total Environment 324, 55-66.

Eggen, R.I.L., Segner, H., 2003. The potential of mechanism-based bioanalytical tools in ecotoxicological exposure and effect assessment. Analytical and Bioanalytical Chemistry, 377, 386-396.

Fenet, H., Gomez, E., Pillon, A., Rosain, D., Nicolas, J.C., Casellas, C., Balaguer, P., 2003. Estrogenic activity in water and sediments of a French river: contribution of alkylphenols. Archives of Environmental Contamination and Toxicology 44, 1-6.

Hartmann, N., Erbs, M., Wettstein, F.E., Schwarzenbach, R.P., Bucheli, T.D., 2007. Quantification of estrogenic mycotoxins at the $\mathrm{ng} / \mathrm{L}$ level in aqueous environmental samples using deuterated internal standards. Journal of Chromatography A, 1138, 132140.

Hollert, H., Durr, M., Olsman, H., Halldin, K., Van Bavel, B., Brack, W., Tysklind, M., Engwall, M., Braunbeck, T., 2002. Biological and chemical determination of dioxin-like 
compounds in sediments by means of a sediment triad approach in the catchment area of the River Neckar. Ecotoxicology 11, 323-336.

Houtman, C.J., Cenijn, P.H., Hamers, T., Lamoree, M.H., Legler, J., Murk, A.J., Brouwer, A., 2004. Toxicological profiling of sediments using in vitro bioassays, with emphasis on endocrine disruption. Environmental Toxicology and Chemistry 23, 32-40.

Houtman, C.J., Booij, P., Jover, E., del Rio, D.P., Swart, K., van Velzen, M., Vreuls, R., Legler, J., Brouwer, A., Lamoree, M.H., 2006. Estrogenic and dioxin-like compounds in sediment from Zierikzee harbour identified with CALUX assay-directed fractionation combined with one and two dimensional gas chromatography analyses. Chemosphere, 65 , 2244-2252.

Jenkins, R.L., Wilson, E.M., Angus, R.A., Howell, W.M., Kirk, M., Moore, R., Nance, M., Brown, A., 2004. Production of androgens by microbial transformation of progesterone in

Jobling, S., Williams, R., Johnson, A., Taylor, A., Gross-Sorokin, M., Nolan, M., Tyler, C.R., van Aerle, R., Santos, E., Brighty, G., 2006. Predicted exposures to steroid estrogens in UK rivers correlate with widespread sexual disruption in wild fish populations.

Kavlock, R.J., Daston, G.P., DeRosa, C., Fenner-Crisp, P., Gray, L.E., Moore, J., Rolland, R., Scott, G., Sheehan, D.M., Sinks, T., 1996. A report of the US EPA-sponsored workshop. Environmental Health Perspectives 107, 715-740.

Kinani, S., Bouchonnet, S., Bourcier, S., Creusot, N., Porcher, J.M., Aït-Aïssa, S., 2008a. Extraction and purification procedures for simultaneous quantification of phenolic xenoestrogens and steroid estrogens in river sediment by gas chromatography/ion trap mass spectrometry. Rapid Communications in Mass Spectrometry 22, 3651-3661. 
532 Kinani, S., Bouchonnet, S., Bourcier, S., Porcher, J.-M., Aït-Aïssa, S., 2008b. Study of the chemical derivatization of zearalenone and its metabolites for gas chromatography-mass spectrometry analysis of environmental samples. Journal of Chromatography A 1190, 307-315.

Labadie, P., Budzinski, H., 2005. Determination of steroidal hormone profiles along the Jalle d'Eysines River (near Bordeaux, France). Environmental Science \& Technology 39, 5113-5120.

Labadie, P., Hill, E.M., 2007. Analysis of estrogens in river sediments by liquid chromatography-electrospray ionisation mass spectrometry - Comparison of tandem mass spectrometry and time-of-flight mass spectrometry. Journal of Chromatography A 1141, $174-181$

Laville, N., Aït-Aïssa, S., Gomez, E., Casellas, C., Porcher, J.M., 2004. Effects of human pharmaceuticals on cytotoxicity, EROD activity and ROS production in fish hepatocytes. Toxicology 196, 41-55.

Laville, N., Balaguer, P., Brion, F., Hinfray, N., Casellas, C., Porcher, J.-M., Aït-Aïssa, S., 2006. Modulation of aromatase activity and mRNA by various selected pesticides in the human choriocarcinoma JEG-3 cell line. Toxicology 228, 98-108.

549 Lemaire, G., Mnif, W., Pascussi, J.M., Pillon, A., Rabenoelina, F., Fenet, H., Gomez, E., Casellas, C., Nicolas, J.C., Cavailles, V., Duchesne, M.J., Balaguer, P., 2006. Identification of new human pregnane $\mathrm{X}$ receptor ligands among pesticides using a stable reporter cell system. Toxicological Sciences 91, 501-509.

Louiz, I., Kinani, S., Gouze, M.E., Ben-Attia, M., Menif, D., Bouchonnet, S., Porcher, J.-M., Ben-Hassine, O.K., Aït-Aïssa, S., 2008. Monitoring of dioxin-like, estrogenic and antiandrogenic activities in sediments of the Bizerta lagoon (Tunisia) by means of in vitro 
cell-based bioassays: contribution of low concentrations of polynuclear aromatic hydrocarbons (PAHs). Science of the Total Environment 402, 318-329.

558 Matejicek, D., Houserova, P., Kuban, V., 2007. Combined isolation and purification procedures prior to the high-performance liquid chromatographic-ion-trap tandem mass spectrometric determination of estrogens and their conjugates in river sediments. Journal of Chromatography A, 1171, 80-89.

Mnif, W., Pascussi, J.-M., Pillon, A., Escande, A., Bartegi, A., Nicolas, J.-C., Cavaillès, V., Duchesne, M.-J., Balaguer, P., 2007. Estrogens and antiestrogens activate hPXR. Toxicology Letters 170, 19-29.

Mossman, T., 1983. Rapid colorimetric assay for cellular growth and survival: application to proliferation and cytotoxicity assays. Journal of Immunology, 65, 55-63.

Muller, M., Rabenoelina, F., Balaguer, P., Patureau, D., Lemenach, K., Budzinski, H., Barcelo, D., De Alda, M.L., Kuster, M., Delgenes, J.P., Hernandez-Raquet, G., 2008. Chemical and biological analysis of endocrine-disrupting hormones and estrogenic activity in an advanced sewage treatment plant. Environmental Toxicology and Chemistry 27, 1649-1658.

Ohtake, F., Takeyama, K., Matsumoto, T., Kitagawa, H., Yamamoto, Y., Nohara, K., Tohyama, C., Krust, A., Mimura, J., Chambon, P., Yanagisawa, J., Fujii-Kuriyama, Y., Kato, S., 2003. Modulation of oestrogen receptor signalling by association with the activated dioxin receptor. Nature 423, 545-550.

Ohtake, F., Baba, A., Takada, I., Okada, M., Iwasaki, K., Miki, H., Takahashi, S., Kouzmenko, A., Nohara, K., Chiba, T., Fujii-Kuriyama, Y., Kato, S., 2007. Dioxin receptor is a ligand-dependent E3 ubiquitin ligase. Nature 446, 562-566.

Ollivon, D., Garban, B., Blanchard, M., Teil, M.J., Carru, A.M., Chesterikoff, C., Chevreuil, M., 2002. Vertical distribution and fate of trace metals and persistent organic pollutants 
in sediments of the Seine and Marne rivers (France). Water Air and Soil Pollution 134, $57-79$.

Pacyniak, E.K., Cheng, X.G., Cunningham, M.L., Crofton, K., Klaassen, C.D., Guo, G.L., 2007. The flame retardants, polybrominated diphenyl ethers, are pregnane $\mathrm{X}$ receptor activators. Toxicological Sciences 97, 94-102.

Pillon, A., Boussioux, A.M., Escande, A., Aït-Aïssa, S., Gomez, E., Fenet, H., Ruff, M., Moras, D., Vignon, F., Duchesne, M.J., Casellas, C., Nicolas, J.C., Balaguer, P., 2005. Binding of estrogenic compounds to recombinant estrogen receptor alpha : Application to environmental analysis. Environmental Health Perspectives, 113, 278-284.

Reddy, S., Brownawell, B.J., 2005. Analysis of estrogens in sediment from a sewageimpacted urban estuary using high-performance liquid chromatography/time-of-flight mass spectrometry. Environmental Toxicology and Chemistry 24, 1041-1047.

Ryan, J.A., Hightower, L.E., 1994. Evaluation of heavy-metal ion toxicity in fish cells using a combined stress protein and cytotoxicity assay. Environmental Toxicology and Chemistry 13, 1231-1240.

Sanchez, W., Katsiadaki, I., Piccini, B., Ditche, J.M., Porcher, J.M., 2008. Biomarker responses in wild three-spined stickleback (Gasterosteus aculeatus L.) as a useful tool for freshwater biomonitoring: A multiparametric approach. Environment International 34, 490-498.

Sanchez, W., Aït-Aïssa, S., Palluel, O., Ditche, J.M., Porcher, J.-M., 2007. Preliminary investigation of multi-biomarker responses in three-spined stickleback (Gasterosteus aculeatus L.) sampled in contaminated streams. Ecotoxicology 16, 279-287. 
estrogenic activity in water bodies receiving cattle feedlot effluent in eastern Nebraska, USA. Environmental Health Perspectives 112, 346-352.

607

608

609

Sumpter, J.P., 2005. Endocrine disrupters in the aquatic environment: An overview. Acta Hydrochimica Et Hydrobiologica 33, 9-16.

Thomas, K.V., Hurst, M.R., Matthiessen, P., McHugh, M., Smith, A., Waldock, M.J., 2002. An assessment of in vitro androgenic activity and the identification of environmental androgens in United Kingdom estuaries. Environmental Toxicology and Chemistry 21, $1456-1461$.

Urbatzka, R., van Cauwenberge, A., Maggioni, S., Vigano, L., Mandich, A., Benfenati, E., Lutz, I., Kloas, W., 2007. Androgenic and antiandrogenic activities in water and sediment samples from the river Lambro, Italy, detected by yeast androgen screen and chemical analyses. Chemosphere, 67, 1080-1087.

Vethaak, A.D., Lahr, J., Schrap, S.M., Belfroid, A.C., Rijs, G.B.J., Gerritsen, A., de Boer, J., Bulder, A.S., Grinwis, G.C.M., Kuiper, R.V., Legler, J., Murk, T.A.J., Peijnenburg, W., Verhaar, H.J.M., de Voogt, P., 2005. An integrated assessment of estrogenic contamination and biological effects in the aquatic environment of The Netherlands. Chemosphere 59, 511-524.

Vindimian, E., Robault, C., Fillion, G., 1983. A method for co-operative and non co-operative binding studies using non-linear regression analysis on a microcomputer. Journal of Applied Biochemistry, 5, 261-268.

Vos, J.G., Dybing, E., Greim, H.A., Ladefoged, O., Lambre, C., Tarazona, J.V., Brandt, I., Vethaak, A.D., 2000. Health effects of endocrine-disrupting chemicals on wildlife, with special reference to the European situation. Critical Reviews in Toxicology 30, 71-133.

Wilson, V.S., Bobseine, K., Lambright, C.R., Gray, L.E., 2002. A novel cell line, MDA-kb2, that stably expresses an androgen- and glucocorticoid-responsive reporter for the 

81.

\section{Figure legends}

633

634 Figure 1. Doses-response curves for EROD induction by sediment organic extracts in PLHC-1 635 cells measured after (a) $4 \mathrm{~h}$ and (b) $24 \mathrm{~h}$ exposure periods. Numbers correspond to the different 636 sites, with 1: Lez, 2: Rev, 3: Rho, 4: VdV, 5: Ais. Values represent the mean \pm SD, $n=3$.

638 Figure 2. Linear regression (log scale) showing correlation between PLHC-1 bioassay- (Bio-) 639 and PAH chemical analyses- (Chem-) derived BaP-EQs (a) and TCDD-EQs (b) in sediment 640 samples.

642 Figure 3. Estrogenic activity of (a) 17ß-estradiol and (b) the five sediment extracts (1: Rev, 2: 643 Rho, 3: VdV, 4: Ais, 5: Lez) in MELN cells. Results are expressed as percentage of maximal 644 luciferase activity induced by $\beta$-E2 at $10 \mathrm{nM}$. Values are means of triplicates \pm SD.

646 Figure 4. (a) Androgenic and (b) anti-androgenic activities of the reference chemicals 647 [dihydrotestosterone (DHT) and Flutamide (Flu)] and sediment extracts in MDA-kb2 cells. 648 Results are expressed as percentage of the maximal luciferase activity induced by DHT at (a) $64910 \mathrm{nM}$ and (b) $0.3 \mathrm{nM}$. Values are means of triplicates \pm SD.

650

651 Figure 5. (a) PXR-mediated dose-response curves of reference chemical (SR 12813) and 652 sediment extracts (1: Rev, 2: Rho, 3: Lez, 4: VdV, 5: Ais) in $\mathrm{HG}_{5} \mathrm{LN}-\mathrm{PXR}$ cells. Results are 653 expressed as percentage of maximal luciferase activity induced by SR 12813 at $0.3 \mu \mathrm{M}$. (b) 654 Non specific effect of sediment extracts on constitutive luciferase expression in $\mathrm{HG}_{5} \mathrm{LN}$ cells. 655 Results are expressed as percentage of luciferase activity in control cells. Values are means of 656 triplicates $\pm \mathrm{SD}$. 
659 Table 1. Summary of some general characteristics of sampling sites

660

\begin{tabular}{|c|c|c|c|c|c|}
\hline Sites & $\begin{array}{l}\text { Aisne } \\
\text { (Ais) }\end{array}$ & $\begin{array}{c}\text { Vallon du } \\
\text { Vivier (VdV) }\end{array}$ & $\begin{array}{l}\text { Rhonelle } \\
\text { (Rho) }\end{array}$ & $\begin{array}{l}\text { Réveillon } \\
\text { (Rev) }\end{array}$ & $\begin{array}{l}\text { Lézarde } \\
\text { Lez) }\end{array}$ \\
\hline $\begin{array}{l}\text { GPS } \\
\text { coordinates }\end{array}$ & $\begin{array}{l}\text { N } 49^{\circ} 23^{\prime} 55^{\prime \prime} \\
\text { E } 3^{\circ} 28^{\prime} 31^{\prime \prime}\end{array}$ & $\begin{array}{l}\text { N } 49^{\circ} 43^{\prime} 23^{\prime \prime} \\
\text { E } 0^{\circ} 27^{\prime} 42^{\prime \prime}\end{array}$ & $\begin{array}{l}\text { N 50॰17'49" } \\
\text { E 33 } 32^{\prime} 41^{\prime \prime}\end{array}$ & $\begin{array}{l}\text { N } 48^{\circ} 34^{\prime} 00^{\prime \prime} \\
\text { E } 2^{\circ} 32^{\prime} 09^{\prime \prime}\end{array}$ & $\begin{array}{l}\mathrm{N} 49^{\circ} 34^{\prime} 09^{\prime \prime} \\
\mathrm{E} 0^{\circ} 13 \prime 20^{\prime \prime}\end{array}$ \\
\hline Pressures ${ }^{\mathrm{a}}$ & Low & Mixed & Urban dense & Urban dense & Mixed \\
\hline Water quality ${ }^{\mathrm{b}}$ & Good & Very good & Bad & Very bad & Good \\
\hline 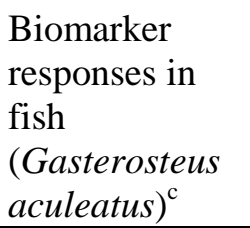 & No data & $\begin{array}{l}\text { No alteration } \\
\text { (reference } \\
\text { site) }\end{array}$ & $\begin{array}{l}\text { Induction of } \\
\text { vitellogenin in } \\
\text { male and } \\
\text { spigging in } \\
\text { female }\end{array}$ & $\begin{array}{l}\text { Induction of } \\
\text { EROD and } \\
\text { vitellogenin in } \\
\text { male }\end{array}$ & $\begin{array}{l}\text { Induction of } \\
\text { EROD }\end{array}$ \\
\hline
\end{tabular}

661

662

663 a, Data obtained from the Rivers Waterbase of the European Environmental Agency (EEA,

664 2008); b, data from obtained from French water agencies; c, data from Sanchez et al. (2008). 
Table 2. Overview of investigated chemicals: chemical families, analytical standard sources and methods used for their quantification in samples

668

\begin{tabular}{|c|c|c|}
\hline $\begin{array}{l}\text { Classes } \\
\text { (Providers) }\end{array}$ & Chemicals & $\begin{array}{l}\text { Analytical methods } \\
\text { (Reference) }\end{array}$ \\
\hline $\begin{array}{l}\text { Natural and } \\
\text { synthetic estrogens } \\
\text { (Sigma-Aldrich) }\end{array}$ & 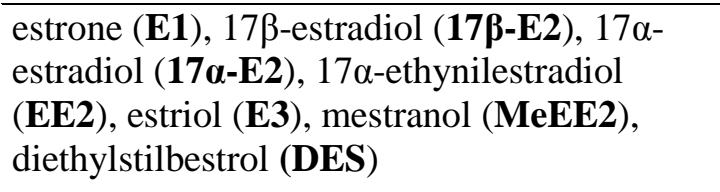 & $\begin{array}{l}\text { GC/MS with derivatization } \\
\text { (Kinani et al., (2008a)) }\end{array}$ \\
\hline $\begin{array}{l}\text { Alkylphenols } \\
\text { (Sigma-Aldrich) }\end{array}$ & $\begin{array}{l}\text { 4-n-nonylphenol (4-n-NP), 4-tert-octylphenol } \\
\text { (4-t-OP), 4-n-butoxyphenol (4-BuOP), 4,4'- } \\
\text { isopropylidene diphenol (bisphenol A, BPA) }\end{array}$ & $\begin{array}{c}\text { GC/MS/MS with } \\
\text { derivatization } \\
\text { (Kinani et al., (2008a)) }\end{array}$ \\
\hline $\begin{array}{l}\text { Parabens } \\
\text { (Sigma-Aldrich) }\end{array}$ & $\begin{array}{l}\text { n-propylparaben }(\mathbf{P r P}), \text { n-butylparaben }(\mathbf{B P}) \text {, } \\
\text { benzylparaben }(\mathbf{B z P})\end{array}$ & $\begin{array}{l}\text { GC/MS and GC/MS/MS with } \\
\text { derivatization } \\
\text { (Kinani et al., (2008a)) }\end{array}$ \\
\hline $\begin{array}{l}\text { hydroxy-PAHs } \\
\text { (Sigma-Aldrich) }\end{array}$ & $\begin{array}{l}\text { 1-hydroxypyrene (1-OHPyr), } 2 \text { - } \\
\text { hydroxyfluorene (2-OHFlu) }\end{array}$ & $\begin{array}{c}\text { GC/MS/MS with } \\
\text { derivatization } \\
\text { (Kinani et al., (2008a)) }\end{array}$ \\
\hline $\begin{array}{l}\text { PAHs } \\
\text { (Sigma-Aldrich) }\end{array}$ & $\begin{array}{l}\text { naphthalene (Nap), acenaphthylene (Acy), } \\
\text { acenaphthene (Ace), fluorene (Flu), } \\
\text { phenanthrene }(\mathbf{P h e}) \text {, anthracene }(\mathbf{A n t}), \\
\text { fluoranthene }(\mathbf{F l t}), \text { pyrene }(\mathbf{P y r}), \\
\text { benz[a] anthracene }(\mathbf{B}[\mathbf{a}] \mathbf{A}), \text { chrysene }(\mathbf{C h r}) \text {, } \\
\text { benzo[b]fluoranthene }(\mathbf{B}[\mathbf{b}] \mathbf{F}), \\
\text { benzo[k]fluoranthene }(\mathbf{B}[\mathbf{k}] \mathbf{F}), \\
\text { benzo[a]pyrene }(\mathbf{B}[\mathbf{a}] \mathbf{P}), \text { indeno[1,2,3- } \\
\text { c,d]pyrene }(\mathbf{I n d}), \text { dibenz[a,h]anthracene } \\
(\mathbf{D B A}), \text { benzo[g,h,i]perylene }(\mathbf{B}[\mathbf{g h i}] \mathbf{P})\end{array}$ & $\begin{array}{l}\text { GC/MS } \\
\text { (Louiz et al., 2008) }\end{array}$ \\
\hline $\begin{array}{l}\text { Organochlorine } \\
\text { pesticides } \\
\text { (Promochem) }\end{array}$ & $\begin{array}{l}\text { hexachlorobenzene (HCB), lindane ( } \gamma \text { - } \\
\text { HCH), vinclozolin, metolachlor, endosulfan } \\
(2 \alpha: 1 \beta), o, p \text { '-DDT, methoxychlor, fenarimol }\end{array}$ & $\begin{array}{l}\text { GC/MS and GC/MS/MS } \\
\text { see section 2.5.1 }\end{array}$ \\
\hline $\begin{array}{l}\text { Phytoestrogens } \\
\text { (Sigma-Aldrich) }\end{array}$ & $\begin{array}{l}\text { daidzein, genistein, biochanin A, equol, } \\
\text { coumestrol, resveratrol }\end{array}$ & $\begin{array}{c}\mathrm{LC} / \mathrm{MS} / \mathrm{MS} \\
\text { see section 2.5.2 }\end{array}$ \\
\hline $\begin{array}{l}\text { Mycoestrogens } \\
\text { (Sigma-Aldrich) }\end{array}$ & $\begin{array}{l}\text { zearalenone }(\mathbf{Z O N}), \alpha \text {-zearalenol }(\boldsymbol{\alpha}-\mathbf{Z O L}) \text {, } \\
\beta \text {-zearalenol }(\boldsymbol{\beta} \text {-ZOL), zearalanone }(\mathbf{Z E A}), \\
\alpha \text {-zearalanol }(\boldsymbol{\alpha} \text {-ZAL) and } \beta \text {-zearalanol }(\boldsymbol{\beta} \text { - } \\
\text { ZAL) }\end{array}$ & $\begin{array}{l}\text { GC/MS with derivatization } \\
\text { (Kinani et al., (2008b)) }\end{array}$ \\
\hline
\end{tabular}


672 Table 3. Concentrations of the 16 PAHs and their relative contribution to the total dioxin-like 673 activity in sediment organic extracts from the five studied sites.

\begin{tabular}{|c|c|c|c|c|c|c|c|c|}
\hline \multirow[b]{2}{*}{ Chemicals } & \multirow{2}{*}{$\begin{array}{c}\mathrm{LOQ}^{\mathrm{a}} \\
(\mathrm{ng} / \mathrm{g})\end{array}$} & \multicolumn{2}{|c|}{$\mathrm{IEF}^{\mathbf{b}}$} & \multicolumn{5}{|c|}{ Concentration in sampling sites in ng/g d.w. } \\
\hline & & $\begin{array}{c}\mathrm{BaP} \\
4 \mathrm{~h} \\
\end{array}$ & $\begin{array}{c}\text { TCDD } \\
24 \mathrm{~h}\end{array}$ & Ais & VdV & Rho & Rev & Lez \\
\hline Nap & 0.11 & n.i. ${ }^{\mathbf{c}}$ & n.i. & n.d. ${ }^{\mathbf{d}}$ & 3.21 & 2.30 & 5.42 & 3.73 \\
\hline Acpy & 0.17 & $5.56 \mathrm{E}-3$ & n.i. & n.d. & 3.57 & 15.28 & 54.96 & 77.27 \\
\hline Acp & 0.08 & n.i. & n.i. & n.d. & 4.94 & 2.56 & 26.18 & 38.66 \\
\hline Flu & 0.09 & $1.44 \mathrm{E}-2$ & n.i. & n.d. & 9.01 & 8.74 & 38.97 & 73.46 \\
\hline Phe & 0.06 & n.i. & n.i. & 10.67 & 132.66 & 96.61 & 612.83 & 1706.67 \\
\hline Ant & 0.11 & n.i. & n.i. & 3.30 & 37.44 & 46.01 & 225.27 & 712.69 \\
\hline Flt & 0.05 & n.i. & n.i. & 46.35 & 307.42 & 267.01 & 1533.00 & 3367.66 \\
\hline Pyr & 0.17 & $3.58 \mathrm{E}-3$ & $3.85 \mathrm{E}-5$ & 36.11 & 231.11 & 168.45 & 1307.67 & 2907.47 \\
\hline $\mathrm{B}[\mathrm{a}] \mathrm{A}$ & 0.06 & $2.58 \mathrm{E}-1$ & $9.77 \mathrm{E}-5$ & 11.14 & 110.79 & 150.53 & 761.47 & 1477.33 \\
\hline Chr & 0.06 & $2.92 \mathrm{E}-1$ & $3.76 \mathrm{E}-4$ & 8.02 & 102.24 & 172.16 & 1013.47 & 1596.00 \\
\hline $\mathrm{B}[\mathrm{b}] \mathrm{F}$ & 0.13 & $6.94 \mathrm{E}-1$ & $4.63 \mathrm{E}-4$ & 15.59 & 69.66 & 723.05 & 2760.67 & 4674.00 \\
\hline $\mathrm{B}[\mathrm{k}] \mathrm{F}$ & 0.11 & 2.94 & $4.23 \mathrm{E}-3$ & 4.14 & 57.38 & 370.71 & 1602.09 & 2681.37 \\
\hline $\mathrm{B}[\mathrm{a}] \mathrm{P}$ & 0.20 & 1 & $5.13 \mathrm{E}-4$ & 15.26 & 97.99 & 138.03 & 841.60 & 1685.49 \\
\hline Ind & 0.07 & $8.43 \mathrm{E}-1$ & $1.64 \mathrm{E}-3$ & 35.76 & 171.62 & 116.08 & 723.40 & 1190.89 \\
\hline DBA & 0.12 & 3.66 & $6.11 \mathrm{E}-3$ & 1.97 & 8.38 & 16.62 & 45.09 & 98.72 \\
\hline $\mathrm{B}$ [ghi]P & 0.16 & n.i. & n.i. & 21.00 & 115.42 & 71.09 & 423.98 & 786.24 \\
\hline \multicolumn{4}{|c|}{ Sum-PAHs (ng/g d.w.) } & 209.3 & 1462.8 & 236.5 & 11976.1 & 23077.7 \\
\hline \multicolumn{4}{|c|}{ Chem-BaP-EQ (ng/g d.w.) } & 81 & 550 & 1978 & 8740 & 15037 \\
\hline \multicolumn{4}{|c|}{ Bio-BaP-EQ (ng/g d.w.) } & 200 & 910 & 7334 & 31556 & 75435 \\
\hline \multicolumn{4}{|c|}{ Chem-BaP-EQ / Bio-BaP-EQ (\%) } & 41 & 60 & 27 & 28 & 20 \\
\hline \multicolumn{4}{|c|}{ Chem-TCDD-EQ (ng/g d.w.) } & 0.11 & 0.72 & 2.35 & 10.45 & 17.78 \\
\hline \multicolumn{4}{|c|}{ Bio-TCDD-EQ (ng/g d.w.) } & 0.67 & 4.49 & 5.89 & 38.43 & 48.38 \\
\hline \multicolumn{4}{|c|}{ Chem-TCDD-EQ / Bio-TCDD-EQ (\%) } & 16 & 16 & 40 & 27 & 37 \\
\hline
\end{tabular}

${ }^{a}$ LOQ: limits of quantification provided by the GC-MS method, ${ }^{\mathbf{b}}$ IEF: induction equivalent factors relative to 679 
Table 4. Concentrations of estrogenic compounds measured in sediment organic extracts from the five studied sites, and their relative contribution to the total estrogenic activity measured in the MELN bioassay.

683

\begin{tabular}{|c|c|c|c|c|c|c|c|c|}
\hline \multirow{2}{*}{$\begin{array}{l}\text { Chemical } \\
\text { classes }\end{array}$} & \multirow{2}{*}{ Chemicals } & \multirow{2}{*}{$\mathrm{EEF}^{\mathrm{a}}$} & \multirow{2}{*}{$\begin{array}{l}\mathrm{LOQ}^{\mathrm{b}} \\
(\mathrm{ng} / \mathrm{g})\end{array}$} & \multicolumn{5}{|c|}{ Concentration in sediment extracts (ng/g d.w.) } \\
\hline & & & & Ais & VdV & Rho & Rev & Lez \\
\hline \multirow{4}{*}{$\begin{array}{l}\text { Natural } \\
\text { estrogens }\end{array}$} & $\alpha-\mathrm{E} 2$ & 0.02 & 0.04 & 0.04 & n.d. & 0.2 & n.d. & n.d. \\
\hline & $\beta-\mathrm{E} 2$ & 1 & 0.05 & 0.27 & 0.78 & 0.58 & 1.58 & 0.18 \\
\hline & E1 & 0.02 & 0.02 & 0.3 & 0.58 & 0.48 & 1.28 & 0.36 \\
\hline & E3 & 0.17 & 0.6 & n.d. & n.d. & n.d. & 1.26 & n.d. \\
\hline \multirow{3}{*}{$\begin{array}{l}\text { Synthetic } \\
\text { estrogens }\end{array}$} & EE2 & 0.93 & 0.07 & n.d. & n.d. & n.d. & n.d. & n.d. \\
\hline & MeEE2 & 0.02 & 0.08 & n.d. & n.d. & n.d. & n.d. & n.d. \\
\hline & DES & 0.17 & 0.03 & n.d. & n.d. & n.d. & n.d. & n.d. \\
\hline \multirow[t]{3}{*}{ Alkylphenols } & 4-t-OP & $1.1 \mathrm{E}-04$ & 0.03 & n.d. & n.d. & 0.56 & 6.3 & n.d. \\
\hline & 4-n-NP & $3.3 \mathrm{E}-06$ & 0.01 & n.d. & 0.52 & n.d. & 0.04 & n.d. \\
\hline & $\mathrm{BPA}$ & $4.5 \mathrm{E}-05$ & 0.01 & 2.29 & 11.67 & 7.92 & 47.28 & 1.24 \\
\hline \multirow[t]{3}{*}{ Parabens } & PrP & $7.4 \mathrm{E}-06$ & $<0.01$ & n.d. & n.d. & n.d. & 0.11 & n.d. \\
\hline & $\mathrm{BuP}$ & $4.9 \mathrm{E}-06$ & $<0.01$ & n.d. & n.d. & n.d. & 0.07 & n.d. \\
\hline & $\mathrm{BzP}$ & $6.6 \mathrm{E}-06$ & 0.02 & n.d. & n.d. & n.d. & 0.79 & n.d. \\
\hline \multirow[t]{2}{*}{$\begin{array}{l}\text { PAHs } \\
\text { metabolites }\end{array}$} & 10HPyr & $9.9 \mathrm{E}-07$ & 0.02 & 0.11 & 0.26 & 0.3 & 0.41 & 0.37 \\
\hline & 2OHFlu & $6.3 \mathrm{E}-06$ & 0.02 & n.d. & n.d. & 0.19 & 0.3 & 0.6 \\
\hline \multirow[t]{3}{*}{ Pesticides } & Endosulfan $(\alpha)$ & $2.0 \mathrm{E}-06$ & 0.21 & n.d. & n.d. & n.d. & 63.84 & n.d. \\
\hline & Endosulfan $(\beta)$ & $2.0 \mathrm{E}-06$ & 1.25 & n.d. & n.d. & n.d. & 29.2 & n.d. \\
\hline & $o, p^{\prime}-\mathrm{DDT}$ & $1.7 \mathrm{E}-05$ & 0.22 & 6.52 & n.d. & n.d. & 7.25 & n.d. \\
\hline Phytoestrogen & Equol & $2.8 \mathrm{E}-04$ & 0.15 & n.d. & n.d. & 0.17 & n.d. & n.d. \\
\hline \multirow[t]{2}{*}{ Mycoestrogens } & $\alpha-\mathrm{ZAL}$ & 0.14 & 0.13 & n.d. & n.d. & n.d. & $<\mathrm{LOQ}$ & n.d. \\
\hline & $\beta-\mathrm{ZAL}$ & 0.03 & 0.02 & n.d. & n.d. & n.d. & $<$ LOQ & n.d. \\
\hline \multicolumn{3}{|c|}{ Chem-E2-EQ (ng/g) ${ }^{\mathrm{d}}$} & - & 0.28 & 0.79 & 0.59 & 1.82 & 0.19 \\
\hline \multicolumn{3}{|c|}{ Bio-E2-EQ (ng/g) ${ }^{\mathrm{e}}$} & 0.010 & 0.29 & 0.83 & 1.69 & 6.43 & 0.20 \\
\hline \multicolumn{3}{|c|}{ Chem-E2-EQ / Biol-E2-EQ (\%) } & & 96 & 95 & 35 & 28 & 94 \\
\hline
\end{tabular}

684
${ }^{a}$ EEF: estradiol equivalence factors relative to estradiol, determined as described in the Materials and Methods section, ${ }^{b}$ LOQ: limit of quantification, ${ }^{c}$ n.d.: not detected or below quantification limits, ${ }^{\mathrm{d}}$ Chem-E2-EQs: chemical estradiol equivalents, ${ }^{\mathrm{e}}$ Biol-E2-EQs: biological estradiol equivalents based on $\mathrm{EC}_{25}$ effective concentration in the MELN bioassay. 
690 Table 5. Summary of anti-androgenic and PXR-mediated activities in sediment extracts and 691 relative contribution of known anti-androgenic and PXR ligands measured in organic extracts 692 from the five studied sites.

693

\begin{tabular}{|c|c|c|c|c|c|c|c|c|}
\hline \multirow{2}{*}{ Chemicals } & \multirow{2}{*}{$\mathrm{FEF}^{\mathrm{a}}$} & \multirow{2}{*}{$\mathrm{SREF}^{\mathrm{a}}$} & \multirow{2}{*}{$\begin{array}{l}\mathrm{LOQ}^{\mathrm{b}} \\
(\mathrm{ng} / \mathrm{g})\end{array}$} & \multicolumn{5}{|c|}{ Concentration at sampling sites (ng/g sed d.w) } \\
\hline & & & & Ais & $\mathrm{VdV}$ & Rho & Rev & Lez \\
\hline BPA & 0.394 & 0.025 & 0.01 & 2.29 & 11.67 & 7.92 & 47.28 & 1.24 \\
\hline 4-t-OP & 0.339 & 0.099 & 0.03 & n.d. & n.d. & 0.56 & 6.3 & n.d. \\
\hline BHT & 0.101 & n.a. & 0.07 & n.d. & 3.13 & 3.6 & 14.14 & 0.61 \\
\hline 4-n-NP & 0.016 & n.a. & 0.01 & n.d. & 0.52 & n.d. & 0.04 & n.d. \\
\hline Endosulfan $(\alpha)$ & 0.058 & 0.029 & 0.21 & n.d. & n.d. & n.d. & 63.84 & n.d. \\
\hline$o, p^{\prime}-\mathrm{DDT}$ & 0.15 & 0.032 & 0.22 & 6.52 & n.d. & n.d. & 7.25 & n.d. \\
\hline Vinclozolin & 2.68 & n.a. & 0.24 & 4.57 & n.d. & n.d. & n.d. & n.d. \\
\hline$\beta-\mathrm{E} 2$ & n.a. & 0.129 & 0.05 & 0.27 & 0.78 & 0.58 & 1.58 & 0.18 \\
\hline E1 & n.a. & 0.13 & 0.02 & 0.3 & 0.58 & 0.48 & 1.28 & 0.36 \\
\hline \multicolumn{3}{|c|}{ Chem-Flu-EQ (ng/g) } & & 14.1 & 4.9 & 3.7 & 27.0 & 0.6 \\
\hline \multicolumn{3}{|c|}{ Bio-Flu-EQ (ng/g) ${ }^{\mathrm{d}}$} & 17.0 & nd & 1089.4 & nd & 32493.4 & 7444.9 \\
\hline \multicolumn{4}{|c|}{ Chem-Flu-EQ / Biol-Flu-EQ (\%) } & - & 0.45 & - & 0.08 & 0.01 \\
\hline \multicolumn{4}{|c|}{ Chem-SR12813-EQ (ng/g) ${ }^{\mathrm{d}}$} & 0.34 & 0.47 & 0.39 & 4.26 & 0.10 \\
\hline \multicolumn{3}{|c|}{ Bio-SR12813-EQ (ng/g) ${ }^{d}$} & 40.0 & 964.8 & 1647.2 & 14322.2 & 51317.3 & 2147.1 \\
\hline \multicolumn{4}{|c|}{ Chem- SR12813-EQ / Biol- SR12813-EQ (\%) } & 0.035 & 0.028 & 0.003 & 0.008 & 0.005 \\
\hline
\end{tabular}

694

$695{ }^{a}$ FEF (Flutamide equivalent factors) were determined as described in Materials and Methods; SREF 696 (SR12813 equivalent factors) were from Lemaire et al. (2004) for endosulfan and from Mnif et al. 697 (2007) for all other compounds. ${ }^{\mathrm{b}}$ LOQ: limit of quantification. n.a.: non active compound, n.d. not 698 detected.

699 